\title{
Thermodynamic equilibria of tailings dump pond water of Sherlovaya Gora tin-polymetallic deposit (Transbaikalia)
}

\author{
Oleg Eremin ${ }^{1, *}$, Olga Rusal ${ }^{1}$, Maria Solodukhina ${ }^{1}$, Ekaterina Epova ${ }^{1}$, and Georgy \\ Yurgenson $^{1}$ \\ ${ }^{1}$ Institute of natural resources, ecology and cryology , Russian Academy of Sciences Siberian Branch, \\ 672014 Chita, Nedorezova street 16a, Russian Federation
}

\begin{abstract}
The potential toxic elements $(\mathrm{Be}, \mathrm{U}, \mathrm{As}, \mathrm{Cd}, \mathrm{Pb}, \mathrm{Sb}, \mathrm{Bi})$ were detected for mine landscape of Sherlovaya Gora tin-polymetallic deposit. Thermodynamic calculation of equilibrium for tailings dump pond water was carried out by means of "Selektor" program complex based on Gibbs free energy minimization algorithm at $25^{\circ} \mathrm{C}$ and 1 bar total pressure. It turned out that the mine water is supersaturated with respect to many sulphates of $\mathrm{Ca}, \mathrm{Mg}, \mathrm{Sr}, \mathrm{Zn}, \mathrm{K}, \mathrm{Cu}, \mathrm{Ni}, \mathrm{Cd}, \mathrm{Be}, \mathrm{Al}, \mathrm{Ce}$ and $\mathrm{Y}$, fluorides of ( $\mathrm{Ln}$ and $\mathrm{Y}, \mathrm{Sc}$ ), and $\mathrm{Y}$ phosphate.
\end{abstract}

\section{Introduction}

Sherlovaya Gora tin-polymetallic deposit is located in the Eastern Transbaikalia and associated with Jurassic magmatic complex represented by granites, liparites, ongonites and other rocks of acid composition [1]. Ores are polymetallic and composed by quartz, tourmaline, chlorite, cassiterite, arsenopyrite, sphalerite, galena, chalcopyrite, pyrite, less common sulphosalts. The deposit represents a large stockwork and about $2 / 3$ of the ore reserves have been mined by an open method since 1962 to 1992. Exploited ore was enriched by a combination technology that included gravity and flotation methods. During the mine work, about 23 thousand tons of ore were produced. After mining finishing the flooding quarry, ore stockpiles, waste rock and tailings dumps are occupying the area of about 4 square kilometers (Fig.1).

The oxidation zone of the mining landscape is composed mainly by sulphates, arsenates, hydroxosulphates and hydroxoarsenates mineral classes [2, 3]. The secondary oxidized minerals are actively formed on the surface of tailings dump, forming the efflorescence and massive clusters in shady areas under waste rocks (Fig. 2). These minerals are highly soluble and almost completely washed away by the rainwater flows into the quarry lake and the tailings dump pond. The tailings dump presents a mining waste sand covered with a ground about $0.5 \mathrm{~m}$ layer on the territory of 53 hectares. The ground layer consists of a mixture of overburden rocks and top soil.

\footnotetext{
${ }^{*}$ Corresponding author: yeroleg@yandex.ru
} 


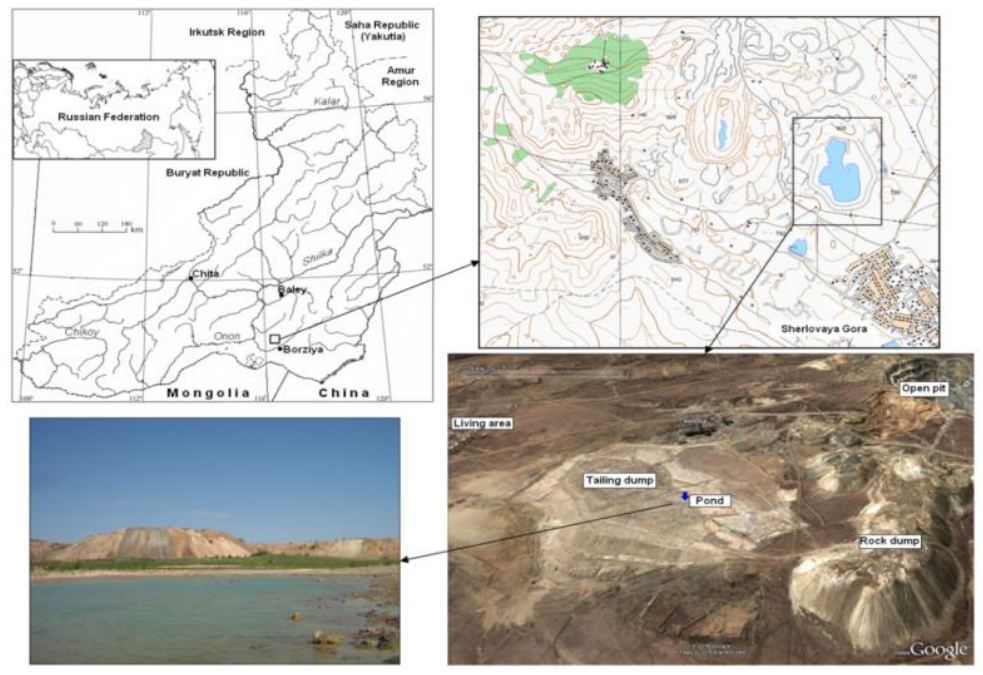

Fig. 1. The tailings dump temporary pond of the Sherlovaya Gora tin-polymetallic deposit.
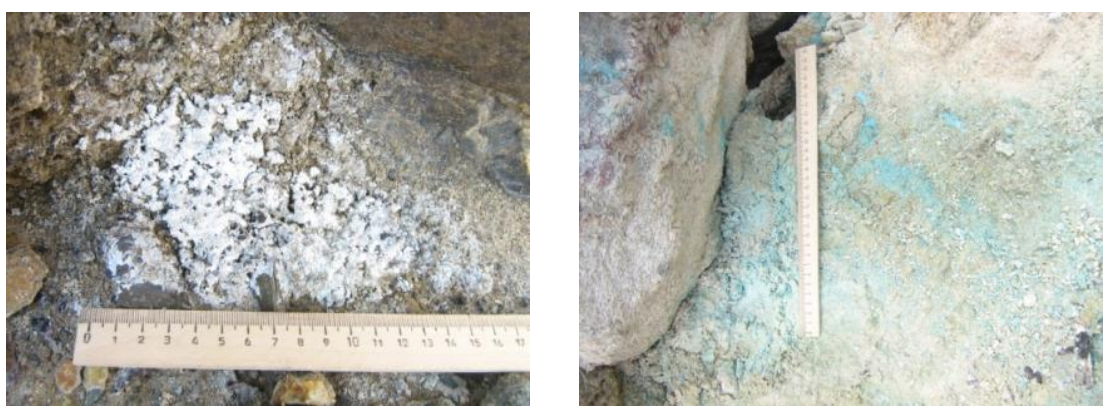

Fig. 2. The associations of hypergene sulphates in shady areas under the waste rocks of the Sherlovaya Gora deposit.

During rainy weather the lowland part of the tailing dump is filled with meteoric waters (Fig.1). In dry time the temporary lake is drained for several days, leaving salts efflorescence in places where solution was present (Fig.3).

The deposit landscapes are characterized by a broad distribution of many metals and metalloids [4]. The objective of this work is to calculate the thermodynamic equilibria for water of tailings dump pond to assess the transport activity of chemical elements and their main mobile species in waste surface waters.

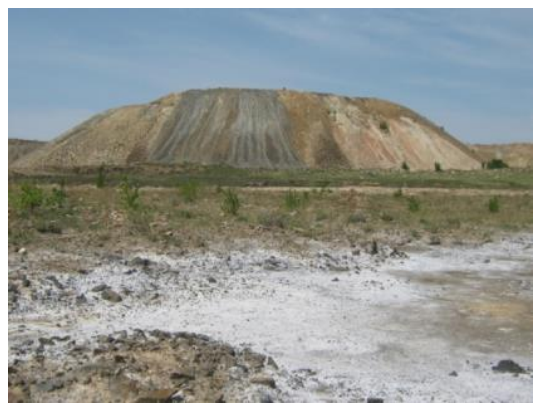

Fig. 3. The salts efflorescence on the edges of the tailings dump pond. 


\section{Materials and methods}

Tailings pond water samples were taken in July 2014 during rainy weather. The $\mathrm{pH}$ and electrode potential of the solution was measured on-site using the "Anion 7000" potentiometer. The chemical composition of water samples was determined by potentiometric, photometric and ICP-MS methods. Water is highly acidic, sulphate, zinkcalcium-magnesium. Based on the obtained data of sampled solution, chemical composition of the model solution was formed.

\section{Thermodynamic model}

Model "aqueous solution-solid phases-atmosphere" system was formed in the "Selektor" program complex [5] and is represented by 1 liter of tailings pond water at $25^{\circ} \mathrm{C}$ and a pressure of 1 bar. The solid phases were presented as minerals (quartz, aluminite, leonite etc.) and solid solutions for chemical classes of sulphates, fluorides, phosphates, zeolites and layered silicates. Thermodynamic properties of the aqueous solution components and solid phases are taken from the "Selektor" thermodynamic databases complemented by data from $[6,7]$, for example the standard Gibbs potential of aluminite was used $G=-4430.8$ $\mathrm{kJ} / \mathrm{mole}$. The results of calculations are presented in Table.

Table. The results of calculation of the thermodynamic equilibria of tailings dump pond water of Sherlovaya Gora tin-polymetallic deposit.

\begin{tabular}{|c|c|c|c|c|}
\hline Components & $\begin{array}{l}\text { Analytical total } \\
\text { aqueous } \\
\text { concentrations }\end{array}$ & $\begin{array}{l}\text { Equilibrium } \\
\text { total aqueous } \\
\text { concentrations }\end{array}$ & $\begin{array}{c}\text { Main } \\
\text { equilibrium } \\
\text { aqueous } \\
\text { species }\end{array}$ & Solid phases \\
\hline $\mathrm{pH}$ & 2.3 & 2.3 & - & - \\
\hline Eh, mV & 450 & 550 & - & - \\
\hline $\mathrm{t},{ }^{\circ} \mathrm{C}$ & 23 & 25 & - & - \\
\hline \multicolumn{5}{|c|}{ Major components, $\mathbf{m g} / \mathbf{L}$} \\
\hline $\mathrm{SO}_{4}^{2-}$ & 5800 & 3890 & $\begin{array}{c}\mathrm{SO}_{4}^{2-}, \mathrm{HSO}_{4}^{-} \\
\mathrm{MeSO}_{4}\end{array}$ & $\begin{array}{c}\mathrm{Ca}, \mathrm{Mg}, \mathrm{Sr}, \mathrm{Zn}, \mathrm{K}, \mathrm{Cu}, \mathrm{Ni}, \mathrm{Cd}, \\
\mathrm{Be}, \mathrm{Al}) \text { sulphates- } 994.78 \\
\text { mg } \\
(\mathrm{Ce}, \mathrm{Y}) \text { sulphates- } 2.55 \mathrm{mg}\end{array}$ \\
\hline $\mathrm{Cl}^{-}$ & 30 & 30 & $\begin{array}{l}\mathrm{HCl}(\mathrm{aq}), \mathrm{Cl}^{-}, \\
\mathrm{MeCl},\end{array}$ & \\
\hline $\mathrm{F}^{-}$ & 1.05 & 0.47 & $\mathrm{HF}, \mathrm{F}^{-}, \mathrm{MeF}$ & $(\mathrm{Ln}, \mathrm{Sc})$ ftorides $-1.16 \mathrm{mg}$ \\
\hline $\mathrm{P}$ & 0.77 & - & & $\begin{array}{c}\text { Xenotime }\left(\mathrm{YPO}_{4}\right)-4.57 \\
\mathrm{mg}\end{array}$ \\
\hline $\mathrm{Si}$ & 37 & 36.73 & $\begin{array}{c}\mathrm{SiO}_{4}^{4-} \\
\mathrm{H}_{2} \mathrm{SiO}_{4}{ }^{2-}\end{array}$ & Opal $\left(\mathrm{SiO}_{2}\right)$ \\
\hline $\mathrm{Ca}$ & 489.811 & 256 & $\begin{array}{l}\mathrm{Ca}^{2+}, \mathrm{CaSO}_{4} \\
\mathrm{CaF}^{+}, \mathrm{CaCl}^{+}\end{array}$ & Gypsum $\left(\mathrm{CaSO}_{4} \cdot 2 \mathrm{H}_{2} \mathrm{O}\right)$ \\
\hline $\mathrm{Mg}$ & 407.757 & 401 & $\begin{array}{l}\mathrm{Mg}^{2+}, \mathrm{MgSO}_{4} \\
\mathrm{MgF}^{+}, \mathrm{MgCl}^{+}\end{array}$ & Epsomite $\left(\mathrm{MgSO}_{4} \cdot 7 \mathrm{H}_{2} \mathrm{O}\right)$ \\
\hline $\mathrm{Sr}$ & 0.853 & 0.071 & $\mathrm{Sr}^{2+}, \mathrm{SrCl}^{+}$ & Celestine $\left(\mathrm{SrSO}_{4}\right)$ \\
\hline $\mathrm{Na}$ & 125.653 & 125.653 & $\begin{array}{l}\mathrm{Na}^{+}, \mathrm{NaCl} \\
\mathrm{NaSO}_{4}^{-}\end{array}$ & - \\
\hline $\mathrm{K}$ & 12.7 & - & - & $\begin{array}{c}\text { Leonite } \\
\left(\mathrm{K}_{2} \mathrm{Mg}\left(\mathrm{SO}_{4}\right)_{2} \cdot 4 \mathrm{H}_{2} \mathrm{O}\right)\end{array}$ \\
\hline $\mathrm{Al}$ & 104.94 & - & - & $\begin{array}{c}\text { Aluminite } \\
\left(\mathrm{Al}_{2} \mathrm{SO}_{4} \mathrm{OH} \cdot 7 \mathrm{H}_{2} \mathrm{O}\right)\end{array}$ \\
\hline $\mathrm{Zn}$ & 859.772 & 850 & $\mathrm{Zn}^{2+}$ & Goslarite $\left(\mathrm{ZnSO}_{4} \cdot 7 \mathrm{H}_{2} \mathrm{O}\right)$ \\
\hline
\end{tabular}




\begin{tabular}{|c|c|c|c|c|}
\hline & & & $\begin{array}{c}\mathrm{ZnSO}_{4}, \mathrm{ZnCl}^{+}, \\
\mathrm{ZnF}^{+} \\
\end{array}$ & \\
\hline $\mathrm{Mn}$ & 351.978 & 351.978 & $\begin{array}{c}\mathrm{Mn}^{2+}, \mathrm{MnSO}_{4}, \\
\mathrm{MnCl}^{+}\end{array}$ & - \\
\hline $\mathrm{Cd}$ & 26 & 24 & $\begin{array}{l}\mathrm{Cd}^{2+}, \mathrm{CdSO}_{4} \\
\mathrm{CdCl}^{+}\end{array}$ & $\mathrm{CdSO}_{4}$ (in solid solution) \\
\hline $\mathrm{Ni}$ & 15.9 & 15.74 & $\mathrm{Ni}^{2+}, \mathrm{NiSO}_{4}$ & Morenosite $\left(\mathrm{NiSO}_{4} \cdot 7 \mathrm{H}_{2} \mathrm{O}\right)$ \\
\hline $\mathrm{Cu}$ & 15 & 14.6 & $\begin{array}{l}\mathrm{Cu}^{2+}, \mathrm{CuSO}_{4}, \\
\mathrm{CuCl}^{+}\end{array}$ & $\begin{array}{l}\text { Chalcanthite } \\
\left(\mathrm{CuSO}_{4} \cdot 5 \mathrm{H}_{2} \mathrm{O}\right)\end{array}$ \\
\hline $\mathrm{Pb}$ & 1.86 & 1.86 & $\begin{array}{l}\mathrm{Pb}^{2+}, \mathrm{PbSO}_{4}, \\
\mathrm{PbF}_{3}^{-}, \mathrm{PbCl}^{+},\end{array}$ & 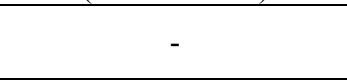 \\
\hline Co & 4.730 & 4.73 & $\begin{array}{c}\mathrm{Co}^{2+}, \mathrm{CoSO}_{4}, \\
\mathrm{CoCl}^{+}\end{array}$ & - \\
\hline $\mathrm{Y}$ & 5.08 & 0.283 & $\mathrm{Y}^{3+}$ & $\begin{array}{l}\mathrm{YF}_{3}, \mathrm{YPO}_{4}, \mathrm{Y}\left(\mathrm{SO}_{4}\right)_{3} \cdot 8 \mathrm{H}_{2} \mathrm{O} \\
\quad \text { (in solid solutions) }\end{array}$ \\
\hline \multicolumn{5}{|c|}{ Minor components, $\mu \mathrm{g} / \mathrm{L}$} \\
\hline $\mathrm{Fe}$ & 370 & - & - & $\begin{array}{c}\text { Ferricopiapite } \\
\left(\mathrm{Fe}_{5}\left(\mathrm{SO}_{4}\right)_{6} \mathrm{OOH} \cdot 20 \mathrm{H}_{2} \mathrm{O}\right)\end{array}$ \\
\hline $\mathrm{Ba}$ & 20 & 20 & $\begin{array}{l}\mathrm{Ba}^{2+}, \mathrm{BaSO}_{4}, \\
\mathrm{BaCl}^{+}\end{array}$ & 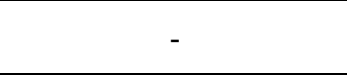 \\
\hline $\mathrm{Be}$ & 504 & 290 & $\begin{array}{c}\mathrm{Be}^{2+}, \\
\mathrm{Be}(\mathrm{OH}) 4^{2-}\end{array}$ & $\mathrm{BeSO}_{4}$ (in solid solution) \\
\hline $\mathrm{Bi}$ & 0.76 & 0.76 & $\mathrm{BiCl}_{4}^{+}$ & - \\
\hline In & 0.5 & 0.5 & $\begin{array}{l}\mathrm{In}^{3+}, \mathrm{InCl}_{2}^{+}, \\
\mathrm{InF}_{2}^{+}\end{array}$ & - \\
\hline $\mathrm{Li}$ & 740 & 740 & $\mathrm{Li}^{+}$ & - \\
\hline $\mathrm{Rb}$ & 140 & 140 & $\mathrm{Rb}^{+}$ & - \\
\hline As & 103 & 103 & $\mathrm{HAsO}_{4}{ }^{2-}$ & - \\
\hline $\mathrm{Sb}$ & 1.58 & 1.58 & $\begin{array}{l}\mathrm{HSbO}_{2} \\
\mathrm{Sb}(\mathrm{OH})_{4}^{-}\end{array}$ & - \\
\hline Mo & 11 & 11 & $\begin{array}{c}\mathrm{HMoO}_{4}^{-} \\
\mathrm{MoO}_{4}^{-} \\
\end{array}$ & - \\
\hline $\mathrm{V}$ & 777 & 777 & $\begin{array}{c}\mathrm{V}_{4} \mathrm{O}_{12}{ }^{4-} \\
\mathrm{H}_{3} \mathrm{VO}_{4}, \mathrm{VO}_{2}^{+}\end{array}$ & - \\
\hline $\mathrm{Sc}$ & 11 & 0.3 & $\mathrm{Sc}^{3+}$ & $\mathrm{ScF}_{3}$ (in solid solution) \\
\hline Ln & 4629 & 1989 & $\mathrm{Ln}^{3+}, \mathrm{LnSO}_{4}^{+}$ & $\begin{array}{c}\mathrm{LnF}_{3} \text {-solid solution, } \\
\mathrm{Ce}\left(\mathrm{SO}_{4}\right)_{3} \cdot 8 \mathrm{H}_{2} \mathrm{O} \text { (in solid } \\
\text { solutions) }\end{array}$ \\
\hline $\mathrm{U}$ & 603 & 603 & $\mathrm{UO}_{2} \mathrm{~F}_{4}{ }^{2-}$ & - \\
\hline $\mathrm{Th}$ & 4 & 4 & $\mathrm{Th}\left(\mathrm{SO}_{4}\right)_{3}{ }^{2-}$ & - \\
\hline
\end{tabular}

Note. A dash(-)is the absence of compounds at equilibrium. Me is the metal cations.

\section{Results and discussion}

The table data show that the tailings pond water is oversaturated by sulphate, fluoride and phosphate minerals that lead to precipitation of main solution cations $-\mathrm{Ca}, \mathrm{Mg}$ and others. A sulphate minerals and their solid solutions present the main mass of sediment. Basically it consists from sulphates of calcium, magnesium, zinc with impurities of cadmium, nickel, copper, beryllium, cerium and yttrium. Some of these impurity elements are not likely to form own mineral phases in natural conditions. For example, to present day not any minerals of beryllium sulphates were discovered. The minerals of the sulphate class are widely expanded in the supergene zone of the deposit. They form association of kieserite $\left(\mathrm{MeSO}_{4} \cdot \mathrm{H}_{2} \mathrm{O}\right)$, rozenite $\left(\mathrm{MeSO}_{4} \cdot 4 \mathrm{H}_{2} \mathrm{O}\right)$, chalcanthite $\left(\mathrm{MeSO}_{4} \cdot 5 \mathrm{H}_{2} \mathrm{O}\right)$, hexahydrite $\left(\mathrm{MeSO}_{4} \cdot 6 \mathrm{H}_{2} \mathrm{O}\right)$, epsomite $\left(\mathrm{MeSO}_{4} \cdot 7 \mathrm{H}_{2} \mathrm{O}\right)$, melanterite $\left(\mathrm{MeSO}_{4} \cdot 7 \mathrm{H}_{2} \mathrm{O}\right)$ groups of minerals, 
where Me is the divalent cations of iron, magnesium, copper, zinc, nickel and cobalt $[8,9]$. The secondary sulphate phases are characterized by complex chemical composition with a wide cationic and anionic isomorphism. So, we separated a zinc-isomorphic melanterite of the composition $\mathrm{Fe}_{0.439} \mathrm{Zn}_{0.418} \mathrm{Mg}_{0.094} \mathrm{Cu}_{0.011} \mathrm{Mn}_{0.009} \mathrm{Ni}_{0.008} \mathrm{Cd}_{0.001} \mathrm{Al}_{0.013} \mathrm{SO}_{4} \cdot 6.546 \mathrm{H}_{2} \mathrm{O}$ [10]. Chemical analysis of hypergene sulphate minerals showed that they are largely enriched in lanthanides of yttrium group and exceed Clarks of the earth crust several times [4].

Metals which fully precipitate from pond water into the solid sediment are represented by potassium, aluminum and iron which respectively form the minerals leonite, aluminite and ferricopiapite. The phosphate anions completely form xenotime. Conservative elements in the tailings water are chloride, arsenic, sodium, manganese, lead, cobalt, barium, bismuth, indium, lithium, antimony, molybdenum, vanadium, uranium and thorium.

Waste drainage water is characterized by increased acidity due to active oxidation of sulfide minerals. Due to the high acidity of the solutions, a large portion of metals is dissolved, it is observed even for relatively high concentrations of slowly soluble lead cations. The main transporting ligands of the metals are sulphate anions, whereas fluoride and phosphate play a function of sedimentation ligands for lanthanides, yttrium and scandium. Uranium migrates in the form of uranyl fluoride unlike most natural environments where it forms carbonate complexes.

Many of the soluble forms of metals and metalloids, such as lead, arsenic, antimony, bismuth, beryllium, uranium, etc. pose an environmental hazard, as they can be widely spread in the components of the landscape and can get through groundwater, domestic animal and vegetable farms into the human body.

\section{Conclusion}

The potential toxicants to the environment and human health were detected for landscape of Sherlovaya Gora deposit. The main transporting forms of chemical elements and precipitating phases from surface waters were determined for composition of tailings dump solution on the basis of chemical analysis and thermodynamic calculations. In particular almost $1 \mathrm{~g}$ of sulphate minerals and solid solutions can precipitate from each liter of water. This precipitating geochemical barrier can inhibit the migration of toxic elements over time. However, the equilibrium concentrations of $\mathrm{Zn}, \mathrm{Cu}, \mathrm{Be}, \mathrm{Cd}, \mathrm{Ni}, \mathrm{V}, \mathrm{Co}, \mathrm{Pb}, \mathrm{Li}, \mathrm{Mn}, \mathrm{As}, \mathrm{U}$, $\mathrm{Ln}$, and sulphate anions remain above the MPC. The main aqueous species of metals are most toxic aquated cations. Phases not typical for hydrogenic mineral formation are noted. They present by $(\mathrm{Be}, \mathrm{Y}, \mathrm{Ce})$ sulfates and fluorides of rare-earth elements in solid solutions, which allows to specify the areas of stability of these compounds and use them for environmental or prospecting purposes.

\section{References}

1. B.A. Gaivoronskii, Sherlovogorskoye Deposit. In: Deposits of Transbailalia (Geoinformmark Publ, Moscow, Book 1, 130-133, 1995) (in Russian)

2. A.V. Kasatkin, K.I. Klopotov, J. Plášil, Min. Alm. 19, 94 (2014)

3. M.A. Solodukhina, G.A. Yurgenson, Arsenic in landscapes of Sherlovaya Gora mining (Eastern Transbaikalia) (Chita, ZabSU, 2018) (in Russian)

4. E.S. Epova, O.S. Rusal', O.V. Eremin, Bull. Tomsk Polytec. Univ. Geo Ass. Eng, 329, 88 (2018)

5. K.V. Chudnenko, Thermodynamic modelling in geochemistry: the theory, algorithms, examples (Publishing house GEO, Novosibirsk, 2010) (in Russian) 
6. O.V. Eremin, O.S. Rusal', V.A. Bychinskii, K.V. Chudnenko, S.V. Fomichev, V.A. Krenev, Rus. J. Inorg. Ch. 60, 950 (2015)

7. A. Migdisov, A. Williams-Jones, J. Brugger, F. Caporuscio, Chem. Geol. 439, 13 (2016)

8. G.A. Yurgenson, O.S. Rusal', Lithosphere, 5, 129 (2014) (in Russian)

9. O.S. Rusal', Vest. Tomsk St. Univ., 400, 414 (2015) (in Russian)

10. O.V. Eremin, O.S. Rusal, E.S. Epova, G.A. Yurgenson, Min. Tech. 16, 204 (2015) (in Russian) 